\title{
Emerging ideas and tools to study the emergent properties of the cortical neural circuits for voluntary motor control in non-
}

\section{human primates [version 1; peer review: 4 approved]}

\author{
John F. Kalaska
}

Groupe de recherche sur le système nerveux central (GRSNC), Département de Neurosciences, Faculté de Médecine, Université de Montréal, C.P. 6128, Succ. Centre-ville, Montréal (Québec), H3C 3J7, Canada

\begin{tabular}{l}
\hline V1 First published: 29 May 2019, 8(F1000 Faculty Rev):749 \\
https://doi.org/10.12688/f1000research.17161.1 \\
Latest published: 29 May 2019, 8(F1000 Faculty Rev):749 \\
https://doi.org/10.12688/f1000research.17161.1 \\
\hline
\end{tabular}

\section{Abstract}

For years, neurophysiological studies of the cerebral cortical mechanisms of voluntary motor control were limited to singleelectrode recordings of the activity of one or a few neurons at a time. This approach was supported by the widely accepted belief that single neurons were the fundamental computational units of the brain (the "neuron doctrine"). Experiments were guided by motor-control models that proposed that the motor system attempted to plan and control specific parameters of a desired action, such as the direction, speed or causal forces of a reaching movement in specific coordinate frameworks, and that assumed that the controlled parameters would be expressed in the task-related activity of single neurons. The advent of chronically implanted multi-electrode arrays about 20 years ago permitted the simultaneous recording of the activity of many neurons. This greatly enhanced the ability to study neural control mechanisms at the population level. It has also shifted the focus of the analysis of neural activity from quantifying single-neuron correlates with different movement parameters to probing the structure of multineuron activity patterns to identify the emergent computational properties of cortical neural circuits. In particular, recent advances in "dimension reduction" algorithms have attempted to identify specific covariance patterns in multi-neuron activity which are presumed to reflect the underlying computational processes by which neural circuits convert the intention to perform a particular movement into the required causal descending motor commands. These analyses have led to many new perspectives and insights on how cortical motor circuits covertly plan and prepare to initiate a movement without causing muscle contractions, transition from preparation to overt execution of the desired movement, generate muscle-centered motor output commands, and learn new motor skills. Progress is also being made to import optical-imaging and optogenetic toolboxes from rodents to non-human primates to overcome some technical limitations of multi-electrode recording technology.

\section{Open Peer Review

\begin{tabular}{|c|c|c|c|}
\hline \multicolumn{4}{|c|}{ Approval Status $\checkmark \checkmark \checkmark \checkmark$} \\
\hline 1 & 2 & 3 & 4 \\
\hline
\end{tabular} \\ version 1 \\ 29 May 2019 \\ Faculty Reviews are review articles written by the prestigious Members of Faculty Opinions. The articles are commissioned and peer reviewed before publication to ensure that the final, published version is comprehensive and accessible. The reviewers who approved the final version are listed with their names and affiliations.}

1. Steve Chase, Carnegie Mellon University, Pittsburgh, USA

2. John P Cunningham, Columbia University, New York, USA

3. Byron Yu, Carnegie Mellon University, Pittsburgh, USA

\section{Hansjörg Scherberger, University of} Göttingen, Göttingen, Germany Any comments on the article can be found at the end of the article. 


\section{Keywords}

cortical control of movement, representational models, dynamical neural networks, dimension reduction analysis, latent variables,

neural manifolds, Ca++ reporter optical imaging

Corresponding author: John F. Kalaska (john.francis.kalaska@umontreal.ca)

Author roles: Kalaska JF: Conceptualization, Writing - Original Draft Preparation, Writing - Review \& Editing

Competing interests: No competing interests were disclosed.

Grant information: This work was supported by the Canadian Institutes of Health Research (MOP 142220).

The funders had no role in study design, data collection and analysis, decision to publish, or preparation of the manuscript.

Copyright: ( 2019 Kalaska JF. This is an open access article distributed under the terms of the Creative Commons Attribution License, which permits unrestricted use, distribution, and reproduction in any medium, provided the original work is properly cited.

How to cite this article: Kalaska JF. Emerging ideas and tools to study the emergent properties of the cortical neural circuits for voluntary motor control in non-human primates [version 1; peer review: 4 approved] F1000Research 2019, 8(F1000 Faculty Rev):749 https://doi.org/10.12688/f1000research.17161.1

First published: 29 May 2019, 8(F1000 Faculty Rev):749 https://doi.org/10.12688/f1000research.17161.1 


\section{Introduction}

For many years, neural recording studies of the cerebral cortical control of voluntary movements in awake, behaving animals were dominated by attempts to correlate the task-related activity of single neurons to the externally measurable properties of the executed movements. The development of simultaneous multi-neuron recording technologies and much more powerful computers over the past two decades has dramatically enhanced our ability to study cortical motor-control mechanisms. This has also led to translational applications such as brain-machine interfaces (BMIs) that allow non-human primates $(\mathrm{NHPs})^{1-6}$ and paralyzed patients ${ }^{7-11}$ to impose real-time volitional control over computer cursors, robotic neuroprosthetic devices and even their own limb muscles ${ }^{12}$ to perform various tasks. The focus of this review, however, is on how recent advances in quantitative tools to analyze population-level activity patterns are providing new insights into the cortical mechanisms of motor control and motor learning.

\section{Representational models of voluntary motor control}

When single-electrode neurophysiological studies of cortical motor control began in the $1960 \mathrm{~s}^{13,14}$, the field was dominated by "representational" models of brain function, which assumed that the activity of single neurons explicitly expressed specific kinds of information, such as particular properties of a sensory input or motor output. Behavioral and theoretical studies suggested that the conversion of an intention to move into muscle-centered motor commands could be described formally as a sequence of sensorimotor transformations between combinations of sensory and motor-related signals in definable coordinate frameworks, culminating in the generation of a descending motor command ${ }^{15-21}$. Computational models of voluntary motor control assumed that the motor system explicitly planned and controlled the specific features of reaching movements over which we appear able to impose volitional control, such as their direction, endpoint, spatial trajectory, velocity and output forces $^{15-34}$. Representational models of brain function predicted that those controlled properties of movements would be explicitly encoded in the time-varying discharge patterns of single neurons generated while the motor system performed the neural equivalent of solving sets of equations that defined the inverse sensorimotor transformations between desired movement properties and causal muscle activity ${ }^{22-34}$. Neural correlates of the controlled parameters and coordinate transformations therefore would be directly observable in the task-related discharge of single neurons and could be identified by analyzing their activity in different motor tasks. Each neuron's activity should show a consistent correlation to a particular parameter at all times before and during a movement, and the cortical control of movement could be understood by piecing together the contributions made by each neuron.

This conceptual foundation motivated many studies that used a wide variety of tasks to try to identify the motor output parameters and coordinate frameworks expressed by neurons in different cortical motor areas, including the primary motor cortex (M1), dorsal premotor cortex (PMd), ventral premotor cortex (PMv), supplemental motor area (SMA), parietal cortex area 5 (PA5) and adjacent medial intraparietal cortex (MIP). These studies revealed important differences in single-neuron response properties and in the strength and timing of correlations with different motor output parameters both within and across cortical areas that presumably reflected the different roles played by each neural population in motor control $^{22-34}$.

These findings were consistent with the representational perspective on the cortical mechanisms of voluntary motor control. Ultimately, however, they have not provided a consensus as to the identity of the controlled parameter(s) or coordinate transformations that are encoded in any cortical motor area. Reasons for this failure include non-stationary correlations between singleneuron activity and motor output parameters at different times before and during movement, overlapping ranges of properties among neurons in different cortical areas, and partial correlations of single-neuron activity with multiple motor output parameters, in part because different movement parameters are coupled through the laws of motion and limb biomechanics ${ }^{34-38}$. When applied in their most simplistic literal sense-single neurons that unambiguously encode a specific controlled parameter in a specific definable coordinate framework-representational models do not account satisfactorily for the complexity of neural activity during the planning and execution of movements.

\section{Parsing the emergent properties of dynamical cortical motor circuits by dimensionality reduction}

Multi-electrode recordings of the simultaneous activity of many neurons have provided critical neural data to test hypotheses that regard the cortical motor system as dynamical neural circuits whose emergent properties accomplish the computations underlying the planning and execution of voluntary movements ${ }^{34,38-42}$. Here, the term "emergent properties" refers to the computational features of a neural circuit that arise from the interactions among the neurons within the circuit. The input-output transformations that generate a movement emerge as collective properties of the interactions among neurons within the circuits.

This perspective suggests that one cannot fully reveal how cortical circuits control movements by determining single-neuron correlates with different movement properties. Instead, one should analyze the activity of neural ensembles to try to parse out the internal computational structure by which the circuit contributes to movement control. One can envisage that the activity of $n$ recorded neurons comprises an $n$-dimensional "state space" in which each neuron's activity forms one axis (dimension) of that space. The instantaneous activity of the entire recorded population occupies a specific point in that state space at a given moment. The activity generating a given movement traces out a trajectory in that $n$-dimensional space as time progresses. Furthermore, the activity of overlapping subsets of neurons contributing to the unfolding neural trajectory is correlated in different ways via shared input signals and via the synaptic interactions among the neurons in the circuit. Trying to understand what the circuit is doing just by quantifying every neuron's discharge rate at every moment in time is intractable. Instead, a more efficient approach that is now being used is "dimensionality 
reduction" (DR $)^{38-48}$. DR seeks sets of time-varying patterns of response covariation ("latent variables") which are shared by many neurons in the population as well as the weightings that determine how much each neuron's activity contributes to each latent variable. This reduces the entire $n$-dimensional neural activity space into a much more compact and tractable lowdimensional space of latent variables that account for the majority of the total variance of the neural activity and that shape the trajectory of neural population activity through state space. The extracted latent variables capture patterns in the statistical covariance structure of the neural population activity which arise while the cortical neural circuits perform the computations required to generate movements. Rather than trying to identify whether a movement parameter is "encoded" by a single neuron, DR parses the statistical covariance structure of population activity patterns to identify multi-neuron correlates of different computational processes.

DR techniques are diverse and include principal component analysis (PCA), independent component analysis, factor analysis (FA), hidden Markov models, Gaussian process factor analysis, linear discriminant analysis and "demixed" PCA (dPCA) $)^{43-48}$, and other state-space ${ }^{49}$ and factor ${ }^{46,47}$ models. New methods continue to be developed ${ }^{47,50-53}$. All of these methods try to reduce a cost function associated with the covariance structure of the neural activity ${ }^{41,44-46}$. Critically, however, different methods make different assumptions about the statistical structure of the neural data and seek specific features in that structure while ignoring features that might be better captured by other methods ${ }^{45,46}$. Thus, the choice of DR method can impact the interpretation and conclusions drawn from a neural data set. Furthermore, some DR methods, such as PCA, are performed on multi-trial-averaged activity and so can be used to analyze data collected during sequential recording sessions using conventional single electrodes, whereas others are performed on multi-neuron activity recorded during single trials to probe circuit function ${ }^{45-53}$. The key innovation of all DR methods is that they extract task-related patterns of multi-neuron co-modulation of activity-the latent variables - that are not observable when each neuron's activity is processed separately.

DR analyses have yielded a number of novel perspectives on long-standing questions about the cortical control of reaching movements. For instance, classic models of the reaction-time process assume that the onset of a voluntary movement is preceded by essential neural events that prepare the motor system to generate a desired movement before it can emit the motor commands to execute $\mathrm{it}^{22-33,54-58}$. This preparatory activity has been extensively studied in instructed-delay tasks in which subjects are first given an instructional cue that provides information about the intended movement, such as the spatial location of a reach target, and later receive a "GO" signal to make the movement. Many neurons in PMd and M1 show changes in activity during the delay period which vary systematically with the information provided by the cue, such as broad directionally tuned activity as a function of the intended direction, amplitude and speed of the reaching movement ${ }^{22-34,54,59-62}$. Representational models presume that those preparatory neural events implement the sensorimotor transformations that calculate the desired properties of the movement and that the observed single-neuron activity expresses the planned properties of the intended movement ${ }^{22-34,54-62}$.

Initial DR studies suggested a different way to view those neural responses ${ }^{38-44}$. They showed that the preparatory activity of the recorded population occupied a local region within the total possible neural-activity state space, dwelled within that local volume for the duration of the delay period, and then transitioned into movement-execution regions of state space after the GO signal appeared ${ }^{38-41,43-45}$. The instantaneous location of the population activity within the preparatory state-space volume when the GO signal appeared was significantly correlated with the reaction time in each trial ${ }^{63,64}$. The preparatory states prior to different reaching movements occupied different regions of state space and the subsequent movement executionrelated activity for each movement followed a different trajectory through state space after exiting the preparatory state ${ }^{38-41,43-45}$.

Strikingly, a subset of the latent variables extracted from neural activity in the caudal part of PMd during movement execution exhibited strongly rotating trajectories through certain dimensions of state space whose amplitude and phase varied systematically as a function of the initial preparatory state and physical properties of each movement ${ }^{38,40,41,65}$. Those state-space rotations could be simulated by a simple linear dynamical model, suggesting that neural circuits in caudal PMd possessed dynamical properties during movement execution. This is consistent with theoretical models and behavioral evidence that the motor system displays computational properties of a dynamical system ${ }^{66-70}$. A critical feature of a dynamical system is that the change in the system's state at any given moment is determined by its current instantaneous state. This led to the hypothesis that the cortical motor system generates a desired movement by first establishing the corresponding initial preparatory state. Once released from that preparatory state, circuits in caudal PMd contribute to the generation of the motor command by evolving along a neural trajectory in state space pre-determined by the initial preparatory state and driven by its own internal dynamics ${ }^{38-41,71}$. This suggests a biologically plausible mechanism by which the motor cortical circuits can implement computations that accomplish the equivalent of a coordinate transformation between desired movement properties and causal muscle activity ${ }^{34-38}$.

These findings suggested that the widely documented singleneuron response correlates with different motor output parameters such as preparatory activity that predicts the direction, speed and length of an impending movement ${ }^{59-62}$, or that correlates with muscle activity and other evolving properties of the movement during execution ${ }^{34}$ are the local expression of those statespace changes occurring at the population level within the neural circuit $^{38-41,72}$. More recent DR studies have yielded further novel perspectives on the role of preparatory activity and the transition from the preparatory to the movement-execution state.

Classic reaction-time models assume that the initial preparatory neural events are obligatory and must be expressed not 
only during the delay period of instructed-delay tasks but also early in the reaction-time period of non-delayed tasks ${ }^{54-58}$. A single-electrode study that compared PMd activity in reaction-time and instructed-delay tasks found evidence consistent with this prediction but could not distinguish distinct preparatory and movement-execution discharge components in the temporally compressed reaction-time activity ${ }^{54}$. A recent study that addressed this issue with DR tools found evidence that provided stronger support for that prediction of the classic model ${ }^{73}$. The investigators identified latent variables in the preparatory neural activity during an instructed-delay period which were maximally orthogonal to some latent variables extracted from execution-related activity recorded after the GO signal. They then showed that the neural activity recorded during the reactiontime period of two different non-delayed tasks always passed through an activation state resembling the preparatory state of the instructed-delay task before transitioning to the orthogonal movement-execution region of state space.

A long-standing question is why the preparatory activity in PMd during the instructed-delay period does not generate overt muscle contractions and movements ${ }^{62,74,75}$. DR analyses provide one possible explanation ${ }^{75}$. They revealed that the activity state space occupied during instructed-delay tasks could be divided into regions that can generate muscle activity ("output-potent") and regions that cannot ("output-null"). Preparatory activity in PMd during the instructed-delay period is in the output-null region of state space (that is, a "prepare-butwithhold-movement" state). It then transitions into the outputpotent region after the GO signal to generate muscle activity ${ }^{75}$. This was recently extended by a study that found that the preparatory and execution-related regions of state space in $\mathrm{PMd} / \mathrm{M} 1$ are almost completely non-overlapping and nearly maximally orthogonal ${ }^{76}$. This occurred because the overall pattern of discharge correlations between all pairs of neurons in the population during the delay period was very different from that during movement execution, even though many neurons were active during both trial periods. This suggested that the dynamical computational structure and resulting emergent properties of the neural circuits change dramatically and rapidly during the transition from preparatory to movement-execution regions of state space ${ }^{76}$. This could explain how the same neurons can discharge during both preparatory and execution phases of a trial and yet not produce muscle activity during preparation.

An obvious next question is how the dynamical computational structure of the neural circuits changes during the transition from a preparatory state to a movement-execution state. A study using a dPCA analysis of the post-GO activity in a delayed reaching $\operatorname{task}^{65}$ extracted several "condition-variant" latent variables related to the different reaching movements and fixed "condition-invariant" latent variables that were associated with all movements independent of their details. The two sets of latent variables were orthogonal to each other in the dPCA state space. The condition-invariant latent variables explained much more of the total activity variance than the condition-variant latent variables. Importantly, the condition-invariant latent variables appeared to capture the process by which the population transitioned from a stable output-null preparatory region of state space to a dynamical output-potent region of state space that generated the time-varying motor output commands ${ }^{65,71,76}$. This suggests that the condition-invariant activity reflected an internal computational process within the neural circuit that drove the network's dynamics towards a state that can initiate movement without contributing to the planning or control of any feature of the ensuing movement. Similarly, a PCA-based DR analysis of M1 neural activity while monkeys reached to and grasped four different objects in one of eight different target locations (for technical reasons, only 24 of the 32 unique object/ location combinations were used $)^{77}$ found that the largest component of task-related neural variance was condition-invariant. In contrast, condition-specific activity accounted for only about a third as much of the task-related neural variance. Finally, some components of M1 activity might serve primarily to maximize the separation of neural trajectories for different movements that otherwise might approach and become "tangled", resulting in undesired motor outputs ${ }^{78}$.

The novel insight provided by these DR analyses ${ }^{65,71,76-78}$ is that a major component of the task-related activity in M1 reflects aspects of the overall structure of the task such as transitions between stable postures and movement, and may have important functional roles in those processes without contributing directly to the specification of the properties of the motor output. This discharge component had been essentially ignored in prior single-neuron analyses. In contrast, the neural modulations that correlated with specific parameters of the task and that had preoccupied the field for many years comprised a significantly smaller proportion of total task-related neural variance.

\section{Future directions}

The study of population-level activity using DR techniques continues to advance to provide intriguing new perspectives on the cortical mechanisms of voluntary motor control. They suggest that the emergent computational properties of dynamical neural circuits may provide a mechanism by which the cortical motor system can implement implicitly such algorithmic formalisms as sensorimotor coordinate transformations that describe how sensory and central signals may be converted into motor output commands. They indicate that the activity of each neuron is only a local window on the underlying lowdimensional computational processes by which entire neural circuits generate movements ${ }^{34-41,72}$. This does not mean, however, that those single-neuron responses are uninterpretable epiphenomena. These studies confirm rather than refute the descriptions of single-neuron responses revealed in previous studies, while providing new ways of interpreting their nature, origin and role. Furthermore, the fundamental questions that motivated previous single-neuron studies are still valid and largely unanswered. How does the motor system transform diverse signals about the current state of the external world and the peripheral motor system and about the subject's own internal physiological, motivational, and cognitive state into motor commands to generate the appropriate movement in the current context to fulfill a particular goal ${ }^{34-38}$ ? How do these processes allow for the volitional control of different properties of a movement in different contexts, such as speed versus accuracy, straight versus curved reach trajectories ${ }^{79}$ or similar reach trajectories 
of the hand through space performed while holding the arm and hand in different postures ${ }^{80}$ ? What roles do different neural populations and different cortical areas play in these processes and how can one account for the known differences in task-related activity in different cortical areas in a given motor task ${ }^{22-34}$ ? We need to understand what population-level computational processes within and across cortical regions could produce those widely documented single-neuron response correlates and what that reveals about how each population and cortical area contributes to voluntary motor control.

So far, however, most DR studies of cortical motor control have focussed on circuit dynamics in caudal PMd and M1 and how they might contribute to the generation of muscle activity $^{38-41,63-65,71-78}$. Studies must expand into other cortical motor areas and to other behaviors such as grasping actions of the hand. A recent comparative study of sensory versus motor areas ${ }^{81}$ has shown the utility of this approach.

For instance, the latent variables extracted from reach-related activity in SMA do not show rotational dynamics ${ }^{82}$. This indicates that the evidence for rotational dynamics found in caudal $\mathrm{PMd}^{38-41,65}$ is not a trivial or inevitable result of the task or the DR analyses. They also indicate that the two regions make different contributions to the control of reaching. A deeper analysis of the latent-variable structure of the activity in the two regions could help to clarify the nature of those differences. Similar approaches might provide a deeper understanding about the known differences in the directional tuning of M1, PMd and PA5/MIP activity in tasks with different degrees of dissociation of the direction of gaze versus reach ${ }^{29,30}$ and how neural correlates of causal forces are far more prominent in M1 than PA5/MIP during reaching movements with external loads or in isometric-force tasks ${ }^{34,83-86}$.

Two studies used demixed DR to compare the activity of hand grasp-related neurons in $\mathrm{PMv}$ and anterior intraparietal cortex (AIP $)^{87,88}$. Their findings showed several parallels with the reach studies in $\mathrm{PMd} / \mathrm{M1}^{38-41,62-65}$, suggesting some common features in the low-dimensional computational structure of the neural mechanisms underlying both behaviors. For instance, they identified distinct preparatory and execution-related regions of state space. Neural activity followed different trajectories through latent-variable space during both grasp preparation and execution, depending on whether the monkeys performed precision-pinch or power-grip actions, on the spatial orientation of the grasp object, and on whether they used the hand contralateral or ipsilateral to the neural recording site. The findings identified condition-variant and condition-invariant latent variables in the neural activity; the latter accounted for most of the total activity variance and were more prominent during movement execution than preparation. Importantly, they also found differences in the properties of the latent variables in the two areas. For instance, the neural activation state showed more prominent time-dependent changes during preparation in $\mathrm{PMv}$ than in AIP, suggesting that PMv is more implicated than AIP in preparation for the increasingly imminent initiation of movement as the delay period progressed. Neural trajectories in AIP were more closely coupled to the spatial orientation of the grasped object independent of the grasping hand but were more strongly coupled in PMv to the laterality of the hand used. These differences suggest different but overlapping roles for $\mathrm{PMv}$ and AIP in the reach-to-grasp task that, both interestingly and reassuringly, are consistent with earlier studies of singleneuron properties in the same two areas ${ }^{28,33}$. Similarly, activity in M1 during a reach-to-grasp task contained condition-variant latent variables associated with object locations and identities ${ }^{77}$. The level of neural modulation in latent variables associated with object location versus identity shifted progressively in time, so that object location correlates were strongest near the onset of reach and object identity modulations were progressively stronger later in the trial as the hand approached the objects and adjusted its configuration to grasp them.

These various findings also indicate that it should be very informative to extend DR from separate analyses of activity in each cortical motor area to the pooled activity patterns recorded simultaneously in multiple areas of the same monkeys in the same task and using the same DR methods. This might provide unique new insights into how movement-related information is transformed across the distributed cortical motor system during the planning and execution of voluntary movements. DR should also be used to parse out how higher-order cognitive and decision-making processes interact with motor preparatory and execution circuits to select the appropriate action to perform in a given behavioral context $t^{31,32,61,89-95}$. For instance, one study ${ }^{95}$ documented how dorsolateral prefrontal neural populations can simultaneously express both the predominant color and direction of colored-dot random-motion stimuli in separate latent variables but selectively use only the color or the motion direction of the stimulus to choose the direction of a saccadic eye movement in a given trial while discounting the other stimulus property. Finally, to enhance the power of new experiments, we also need more robust hypothesis-validation tools to assess to what degree DR techniques reveal truly novel emergent features of neural circuit processing or simply reflect prior known properties of single-neuron responses ${ }^{72,96}$.

\section{Latent variables, neural manifolds and motor learning}

DR reveals that the covariance patterns of multi-neuron activity during the performance of typical motor tasks such as reaching in $2 \mathrm{D}$ and $3 \mathrm{D}$ physical space occupy a limited region-a "neural manifold"-of the full theoretically possible $n$-dimensional neural state space ${ }^{97-99}$. This neural manifold contains the intrinsic statistical structure (the latent variables) resulting from all the combinations of multi-neuron activity co-modulation patterns within the network which are sufficient to control the movements used in a given task. Recent DR studies that leveraged BMI technology suggest that the neural manifold also determines which motor skills are easy to learn and which are difficult.

In typical BMI tasks, subjects control the movements of an effector such as a cursor on a monitor or a robotic arm by volitional modulation of neural activity recorded by multi-electrode arrays in cortical motor areas ${ }^{1-11}$. A "decoder" algorithm translates the recorded activity into control signals for the effector. The 
unique experimental advantage offered by the decoder is that the recorded neurons are the sole source of its input signals, and the mapping between their activity and effector motions is completely defined by the decoder algorithm. Studies have used BMI tasks to document how subjects learn to control an effector through the decoder and how they alter neural activity patterns as they try to adapt to experimental alterations of the decoder mapping between neural activity and effector motions $\mathbf{s}^{6,100-104}$.

One study ${ }^{97}$ used a BMI paradigm to assess the contribution of the neural manifold to motor learning. At the start of each session, the investigators recorded neural activity in M1 while monkeys controlled cursor motions with a familiar ("intuitive") decoder and used FA to identify the latent variables within the intrinsic neural manifold associated with the intuitive decoder. The investigators then altered the decoder mapping in very specific ways so that the required compensatory changes in recorded neural activity either remained within the intrinsic manifold or had to explore regions of state space outside of the manifold. Within-manifold re-mappings maintained the contributions of each neuron to the latent variables but altered the mapping between the latent variables and cursor motions. This allowed the monkeys to use the familiar covariance patterns of the intuitive manifold but they had to associate them with different movements. Outside-manifold re-mappings altered the way that single neurons contributed to the latent variables but preserved the mapping between each latent variable and cursor motions. This required the monkeys to learn new multi-neuronal activity covariance patterns for each movement.

The monkeys showed considerable adaptation to within-manifold re-mappings over a few hundred trials in a single recording session but very limited ability to adapt to outside-manifold re-mappings within the same time frame ${ }^{97}$. These results suggested that the low-dimensional latent-variable structure within the intrinsic manifold imposes important constraints on motor learning. A subsequent study probed more deeply how the covariance structure of the intrinsic neural manifold associated with the intuitive decoder influenced adaptation to within-manifold perturbations ${ }^{105}$. The optimal solution would be to create a new multi-neuron covariance pattern for each reach direction, essentially a new set of latent variables. Instead, the monkeys tended to retain the latent-variable structure of the intuitive manifold and learned how to reweight and reassign different intrinsic latent variables to new reach directions when the decoder mapping was changed. This also could not be explained by redundancy in muscle activity patterns ${ }^{106}$. This provided further evidence that the circuit dynamics responsible for the multi-neuron co-modulation patterns in the intrinsic manifold, not the activity of single neurons, are the basic computational mechanism of motor control ${ }^{97,105,106}$. This is consistent with other findings that monkeys initially attempt to adapt to decoder perturbations by searching through the neural activity patterns associated with their natural motor repertoire $^{6,107}$.

These results showed that the monkeys could not acquire outside-manifold solutions during a single training session. However, monkeys can adapt to an arbitrary decoder re-mapping if allowed to practice for several training sessions ${ }^{101,102}$. Importantly, this longer-term learning involved changes in both the independent and coordinated variance across neurons ${ }^{108}$. This provided further evidence that the latent-variable structure of the intrinsic manifold allows for rapid motor learning when that structure is preserved but that it can be altered over longer time frames.

\section{Optical imaging and optogenetics}

Neural data collected with chronically implanted multi-electrode arrays have greatly enhanced our ability to study cortical function but this technology still has important technical limitations. Among them, they provide a very sparse sampling of a small fraction of all the neurons within the implanted cortical volume, the neurons are usually unidentified, and the number of isolatable neurons usually declines substantially over several months. Advances in electrode technology may resolve some of these limitations. For instance, newly developed Neuropixel probes carry about 1000 closely spaced recording surfaces on a shaft that is $1 \mathrm{~cm}$ long and $70 \mu \mathrm{m}$ wide ${ }^{109,110}$. They can permit simultaneous observation of the activity of most or all of the hundreds or even thousands of recordable neurons along a long narrow cylindrical volume of neural tissue around the probe. The resulting $1-$ to 2 -order of magnitude increase in the size of neural data sets will present new challenges and opportunities for data analyses $s^{47,109,110}$.

However, a different potential solution to these limitations may be two-photon (2P) optical imaging of neural activity using fluorescent signals generated by $\mathrm{Ca}^{++}$reporter molecules expressed by neurons ${ }^{11-113}$ and optogenetic methods to modulate the activity of targeted neural populations ${ }^{114}$. These techniques have developed rapidly in rodent and other small-animal models. $2 \mathrm{P} \mathrm{Ca}^{++}$imaging allows the simultaneous observation of the spiking activity of most or all single neurons that express the $\mathrm{Ca}^{++}$reporter within a microscope's field of view (FOV). One can reliably image the activity of the same identified neurons within the FOV for many weeks or months. One can locate each neuron within the $3 \mathrm{D}$ cortical volume and reconstruct the spatiotemporal pattern of activity within that cortical volume. Double-labelling of neurons with different markers can allow one to identify specific neural subpopulations within the FOV. One can examine cortical function from the macro level of hundreds to thousands of neurons to the micro level of single dendritic spines. Ultimately, one could link all of these observations about neural activity to computational models of cortical local-circuit function. These tools have been used successfully in rodent studies of motor control and motor learning, and DR has been used on those data to extract features of the computational structure of neural activity ${ }^{115-126}$.

The potential power of optical imaging and optogenetic tools has spurred interest in developing similar toolboxes for NHPs $^{127-131}$. However, progress has been slow because of the lack of the many transgenic lines, promoters and other tools to manipulate gene expression in specific cell types that are available in rodent models. As a result, the field is still largely in the proof-of-concept stage. Nevertheless, successful imaging of fluorescent signals from populations of identified neurons for weeks and months has been demonstrated in several NHP 
species, including macaque monkeys ${ }^{128,132-139}$, squirrel monkeys ${ }^{113}$ and marmosets ${ }^{140-143}$.

Optical-imaging studies of primary visual cortex (V1) in NHPs have successfully reconstructed the functional organization within an FOV, including visual-stimulus orientation bands and other known features of V1 hypercolumn structure ${ }^{134,135}$. They have shown that single layer 2/3 V1 neurons are preferentially activated by relatively complex features of arbitrary visual stimuli such as curvature, junctions and corners ${ }^{136}$ and that the representation of complex natural visual scenes is extremely sparse in layers $2 / 3$ of $\mathrm{V} 1^{137}$. Finally, the activity of 150 to 250 neurons has been imaged in M1 of marmosets while they performed reaching movements or attempted to adapt to external force fields during reaching ${ }^{143}$. These initial results confirm the potential of $2 \mathrm{P}$ optical-imaging methods to study the activity of large populations of identified neurons within an FOV in the cerebral cortex of behaving NHPs over extended periods of time.

Nevertheless, current 2P optical-imaging methods have a number of important limitations. They provide signals about neural spiking activity but not local field potentials. Most $\mathrm{Ca}^{++}$ imaging methods with the spatiotemporal resolution needed to observe the spiking activity of many single neurons can image to a depth of only about $1000 \mu \mathrm{m}$, so that all NHP imaging studies to date have been limited to cortical layers $2 / 3$. Advances in $\mathrm{Ca}^{++}$reporter molecules and imaging optics might eventually extend the depth of imaging ${ }^{129,131,144-146}$, but the light scattering and absorption properties of the heavily myelinated cortical tissue of NHPs present a major technical challenge. Moreover, many important functional areas are buried deep in the sulci of NHPs with gyrencephalic brains, making them inaccessible to direct optical imaging from the cortical surface. Optically refractive GRIN (gradient-index) lenses or periscope-like mirror probes could be inserted into the sulcal folds, but they are relatively large $(>1 \mathrm{~mm})$, can cause tissue damage when inserted, and are too rigid to be appropriate for long-term chronic recordings ${ }^{147}$. Very thin micro-endoscopes that can be inserted to any depth are under development ${ }^{147}$.

Furthermore, the FOV of most optical-imaging studies of multi-neuron spiking activity is relatively small, typically ranging from $500 \times 500 \mu \mathrm{m}$ to $850 \times 850 \mu \mathrm{m}$, and much less when imaging single dendrites or spines. An FOV smaller than $1000 \times 1000 \mu \mathrm{m}$ will image the activity in only a very small part of the entire M1 motor map for the arm or about one visual hypercolumn in V1 of a macaque monkey. This severely constrains the ability to study functional organization over large expanses of a given cortical region. New advances in microscope optics and scanner engines may substantially increase the FOV to dimensions more appropriate for brains of the size in NHPs ${ }^{148-150}$.

Finally, microelectrode recordings of well-isolated neurons provide streams of discrete action potentials that can be measured with millisecond precision. In contrast, the fluorescent optical signals are noisy and indirect signs of neural spiking activity, and measurement and estimation errors are introduced at every stage in the data acquisition and processing pipeline from signal generation to signal measurement and subsequent analysis. The optical-imaging system can observe only the fluorescent photons that happen to enter the optical aperture of the photomultiplier sensor as it raster-scans the FOV. The time course of the fluorescent response to a single spike is slow and prolonged compared with the causal action potential. As a result, the fluorescent signals generated by each spike of a high-frequency multi-spike discharge burst with short inter-spike intervals will sum and deconvolution techniques to reconstruct the causal spike sequence can introduce estimation errors. Fluorescent signals from neurons whose somata overlap visually in the FOV further confound the spike deconvolution process. Motions of the brain during scanning cause shifts of the positions of imaged neurons within the FOV, and techniques to co-register sequentially scanned images can introduce errors in singleneuron alignment across images and in the measurement of each neuron's fluorescent signals across time. These and other sources of measurement and estimation errors may introduce a significant level of uninformative and even potentially misleading noise in the reconstructed multi-neuron activity patterns ${ }^{151}$. This may compromise the ability of methods like DR, that analyze the covariance structure of multi-neuron activity patterns, to parse out the internal computational dynamics of local neural circuits, especially at a temporal resolution approaching that afforded by microelectrode recordings of neural spike trains.

\section{Grant information}

This work was supported by the Canadian Institutes of Health Research (MOP 142220).

The funders had no role in study design, data collection and analysis, decision to publish, or preparation of the manuscript.

\section{Acknowledgements}

I thank Mark Churchland, Dan O'Shea, Paul Cisek and Andrea Green for many invaluable discussions during the preparation of this review and for very constructive comments on early drafts of this manuscript.
1. Serruya MD, Hatsopoulos NG, Paninski L, et al.: Instant neural control of a movement signal. Nature. 2002; 416(6877): 141-2. PubMed Abstract | Publisher Full Text

2. Taylor DM, Tillery SI, Schwartz AB: Direct cortical control of 3D neuroprosthetic devices. Science. 2002; 296(5574): 1829-32. PubMed Abstract | Publisher Full Text

3. F Musallam S, Corneil BD, Greger B, et al:: Cognitive control signals for neural prosthetics. Science 2004; 305(5681): 258-62. PubMed Abstract | Publisher Full Text | F1000 Recommendation

4. $\quad \mathrm{F}$ Velliste M, Perel S, Spalding MC, et al.: Cortical control of a prosthetic arm for self-feeding. Nature. 2008; 453(7198): 1098-101. PubMed Abstract | Publisher Full Text | F1000 Recommendation

5. Revechkis B, Aflalo TN, Kellis S, et al:: Parietal neural prosthetic control of a computer cursor in a graphical-user-interface task. J Neural Eng. 2014; 11(6): 
66014 .

PubMed Abstract | Publisher Full Text | Free Full Text

6. Green AM, Kalaska JF: Learning to move machines with the mind. Trends Neurosci. 2011; 34(2): 61-75.

PubMed Abstract | Publisher Full Text

7. F Hochberg LR, Serruya MD, Friehs GM, et al: Neuronal ensemble control of prosthetic devices by a human with tetraplegia. Nature. 2006; 442(7099): 164-71.

PubMed Abstract | Publisher Full Text | F1000 Recommendation

8. Hochberg LR, Bacher D, Jarosiewicz B, et al:: Reach and grasp by people with tetraplegia using a neurally controlled robotic arm. Nature. 2012; 485(7398): $372-5$.

PubMed Abstract | Publisher Full Text | Free Full Text

9. $\quad \mathrm{F}$ Collinger JL, Wodlinger B, Downey JE, et al.: High-performance neuroprosthetic control by an individual with tetraplegia. Lancet. 2013; 381(9866): 557-64

PubMed Abstract | Publisher Full Text | Free Full Text | F1000 Recommendation

10. Wodlinger B, Downey JE, Tyler-Kabara EC, et al:: Ten-dimensional anthropomorphic arm control in a human brain-machine interface: difficulties, solutions, and limitations. J Neural Eng. 2015; 12(1): 016011.

PubMed Abstract | Publisher Full Text

11. F Aflalo T, Kellis S, Klaes C, et al:: Neurophysiology. Decoding motor imagery from the posterior parietal cortex of a tetraplegic human. Science. 2015 348(6237): 906-10.

PubMed Abstract | Publisher Full Text | Free Full Text | F1000 Recommendation

12. F Bouton CE, Shaikhouni A, Annetta NV, et al.: Restoring cortical control of functional movement in a human with quadriplegia. Nature. 2016; 533(7602) 247-50.

PubMed Abstract | Publisher Full Text | F1000 Recommendation

13. Evarts EV: Relation of pyramidal tract activity to force exerted during voluntary movement. J Neurophysiol. 1968; 31(1): 14-27.

PubMed Abstract | Publisher Full Text

14. Evarts EV: Activity of pyramidal tract neurons during postural fixation. J Neurophysiol. 1969; 32(3): 375-85. PubMed Abstract | Publisher Full Text

15. Morasso P: Spatial control of arm movements. Exp Brain Res. 1981; 42(2): $223-7$.

PubMed Abstract | Publisher Full Text

16. Soechting JF, Terzuolo CA: Sensorimotor transformations underlying the organization of arm movements in three-dimensional space. Can J Physiol Pharmacol. 1988; 66(4): 502-7.

PubMed Abstract | Publisher Full Text

17. Hogan N: Planning and execution of multijoint movements. Can J Physiol Pharmacol. 1988; 66(4): 508-17.

PubMed Abstract | Publisher Full Text

18. Soechting JF, Flanders M: Moving in three-dimensional space: frames of reference, vectors, and coordinate systems. Annu Rev Neurosci. 1992; 15: $167-91$

PubMed Abstract | Publisher Full Text

19. Bullock D, Grossberg S, Guenther FH: A self-organizing neural model of motor equivalent reaching and tool use by a multijoint arm. J Cogn Neurosci. 1993; 5(4): 408-35.

PubMed Abstract | Publisher Full Text

20. McIntyre J, Stratta F, Droulez J, et al.: Analysis of pointing errors reveals properties of data representations and coordinate transformations within the central nervous system. Neural Comput. 2000; 12(12): 2823-55. PubMed Abstract | Publisher Full Text

21. Makin JG, Fellows MR, Sabes PN: Learning multisensory integration and coordinate transformation via density estimation. PLOS Comput Biol. 2013; 9(4): e1003035.

PubMed Abstract | Publisher Full Text | Free Full Text

22. Wise SP: The primate premotor cortex: past, present, and preparatory. Annu Rev Neurosci. 1985; 8: 1-19.

PubMed Abstract | Publisher Full Text

23. Kalaska JF, Crammond DJ: Cerebral cortical mechanisms of reaching movements. Science. 1992; 255(5051): 1517-23.

PubMed Abstract | Publisher Full Text

24. Colby $C L$, Duhamel JR: Spatial representations for action in parietal cortex. Brain Res Cogn Brain Res. 1996; 5(1-2): 105-15.

PubMed Abstract | Publisher Full Text

25. Wise SP, Boussaoud D, Johnson PB, et al:: Premotor and parietal cortex: corticocortical connectivity and combinatorial computations. Annu Rev Neurosci. 1997; 20: 25-42.

PubMed Abstract | Publisher Full Tex

26. Kalaska JF, Scott $\mathrm{SH}$, Cisek $\mathrm{P}$, et al.: Cortical control of reaching movements. Curr Opin Neurobiol. 1997; 7(6): 849-59.

PubMed Abstract | Publisher Full Text

27. Burnod $Y$, Baraduc $P$, Battaglia-Mayer A, et al:: Parieto-frontal coding of reaching: an integrated framework. Exp Brain Res. 1999; 129(3): 325-46. PubMed Abstract | Publisher Full Text

28. Rizzolatti G, Luppino G: The cortical motor system. Neuron. 2001; 31(6): 889-901.

PubMed Abstract | Publisher Full Text
29. Battaglia-Mayer A, Caminiti R, Lacquaniti F, et al:: Multiple levels of representation of reaching in the parieto-frontal network. Cereb Cortex. 2003; 13(10): 1009-22. PubMed Abstract | Publisher Full Text

30. Buneo CA, Andersen RA: The posterior parietal cortex: sensorimotor interface for the planning and online control of visually guided movements. Neuropsychologia. 2006; 44(13): 2594-606

PubMed Abstract | Publisher Full Text

31. Hoshi E, Tanji J: Distinctions between dorsal and ventral premotor areas: anatomical connectivity and functional properties. Curr Opin Neurobiol. 2007; 17(2): 234-42.

PubMed Abstract | Publisher Full Text

32. Tanji J, Hoshi E: Role of the lateral prefrontal cortex in executive behaviora control. Physiol Rev. 2008; 88(1): 37-57.

PubMed Abstract | Publisher Full Text

33. Rizzolatti G, Cattaneo L, Fabbri-Destro M, et al.: Cortical mechanisms underlying the organization of goal-directed actions and mirror neuron-based action understanding. Physiol Rev. 2014; 94(2): 655-706.

PubMed Abstract | Publisher Full Text

34. Kalaska JF: From intention to action: motor cortex and the control of reaching movements. Adv Exp Med Biol. 2009; 629: 139-78.

PubMed Abstract | Publisher Full Tex

35. Fetz EE: Are movement parameters recognizably coded in the activity of single neurons? Behav Brain Sci. 1992; 15(4): 679-690.

Publisher Full Text

36. Scott $\mathrm{SH}$ : Inconvenient truths about neural processing in primary motor cortex. J Physiol. 2008; 586(5): 1217-24. PubMed Abstract | Publisher Full Text | Free Full Text

37. Reimer J, Hatsopoulos NG: The problem of parametric neural coding in the motor system. Adv Exp Med Biol. 2009; 629: 243-59. PubMed Abstract | Publisher Full Text | Free Full Text

38. Shenoy KV, Sahani M, Churchland MM: Cortical control of arm movements: a dynamical systems perspective. Annu Rev Neurosci. 2013; 36: 337-59. PubMed Abstract | Publisher Full Text

39. Churchland MM, Cunningham JP, Kaufman MT, et al.: Cortical preparatory activity: representation of movement or first cog in a dynamical machine? Neuron. 2010; 68(3): 387-400.

PubMed Abstract | Publisher Full Text | Free Full Text

40. F Churchland MM, Cunningham JP, Kaufman MT, et al:: Neural population dynamics during reaching. Nature. 2012; 487(7405): 51-6. PubMed Abstract | Publisher Full Text | Free Full Text | F1000 Recommendation

41. Churchland MM, Cunningham JP: A Dynamical Basis Set for Generating Reaches. Cold Spring Harb Symp Quant Biol. 2014; 79: 67-80. PubMed Abstract | Publisher Full Text

42. F Yuste R: From the neuron doctrine to neural networks. Nat Rev Neurosci. 2015; 16(8): 487-97.

PubMed Abstract | Publisher Full Text | F1000 Recommendation

43. Yu BM, Cunningham JP, Santhanam G, et al:: Gaussian-process factor analysis for low-dimensional single-trial analysis of neural population activity. J Neurophysiol. 2009; 102(1): 614-35. PubMed Abstract | Publisher Full Text | Free Full Text

44. Santhanam G, Yu BM, Gilja V, et al.: Factor-analysis methods for higherperformance neural prostheses. J Neurophysiol. 2009; 102(2): 1315-30. PubMed Abstract | Publisher Full Text | Free Full Text

45. Cunningham JP, Yu BM: Dimensionality reduction for large-scale neura recordings. Nat Neurosci. 2014; 17(11): 1500-9. PubMed Abstract | Publisher Full Text | Free Full Text

46. Cunningham JP, Ghahramani Z: Linear dimensionality reduction: Surveys, insights, and generalizations. J Machine Learning Res. 2015; 16: 2859-2900. Reference Source

47. Paninski L, Cunningham JP: Neural data science: accelerating the experimentanalysis-theory cycle in large-scale neuroscience. Curr Opin Neurobiol. 2018; 50: 232-41.

PubMed Abstract | Publisher Full Text

48. Machens CK: Demixing population activity in higher cortical areas. Front Comput Neurosci. 2010; 4: 126 .

PubMed Abstract | Publisher Full Text | Free Full Text

49. Smith AC, Brown EN: Estimating a state-space model from point process observations. Neural Comput. 2003; 15(5): 965-91.

PubMed Abstract | Publisher Full Text

50. Lakshmanan KC, Sadtler PT, Tyler-Kabara EC, et al.: Extracting Low-Dimensional Latent Structure from Time Series in the Presence of Delays. Neural Comput. 2015; 27(9): 1825-56.

PubMed Abstract | Publisher Full Text | Free Full Text

51. Whiteway MR, Butts DA: Revealing unobserved factors underlying cortical activity with a rectified latent variable model applied to neural population recordings. J Neurophysiol. 2017; 117(3): 919-36. PubMed Abstract | Publisher Full Text | Free Full Text

52. F Pandarinath C, O'Shea DJ, Collins J, et al.: Inferring single-trial neural population dynamics using sequential auto-encoders. Nat Methods. 2018 15(10): 805-15.

PubMed Abstract | Publisher Full Text | Free Full Text | F1000 Recommendation

53. Gao Y, Archer E, Paninski L, et al.: Linear dynamical neural population models through nonlinear embeddings. 30th Conference on Neural Information 
Processing Systems (NIPS). arXiv: 1605.08454v2, 2016 Reference Source

54. Crammond DJ, Kalaska JF: Prior information in motor and premotor cortex: activity during the delay period and effect on pre-movement activity. J Neurophysiol. 2000; 84(2): 986-1005.

PubMed Abstract | Publisher Full Text

55. Wong AL, Haith AM, Krakauer JW: Motor Planning. Neuroscientist. 2015; 21(4): 385-98.

PubMed Abstract | Publisher Full Text

56. Rosenbaum DA: Human movement initiation: specification of arm, direction, and extent. J Exp Psychol Gen. 1980; 109(4): 444-74.

PubMed Abstract | Publisher Full Text

57. Riehle A, Requin J: Monkey primary motor and premotor cortex: single-cell activity related to prior information about direction and extent of an intended movement. J Neurophysiol. 1989; 61(3): 534-49.

PubMed Abstract | Publisher Full Text

58. Riehle A, Requin J: The predictive value for performance speed of preparatory changes in neuronal activity of the monkey motor and premotor cortex. Behav Brain Res. 1993; 53(1-2): 35-49.

PubMed Abstract | Publisher Full Text

59. Messier J, Kalaska JF: Covariation of primate dorsal premotor cell activity with direction and amplitude during a memorized-delay reaching task.

J Neurophysiol. 2000; 84(1): 152-65.

PubMed Abstract | Publisher Full Text

60. Cisek $P$, Crammond DJ, Kalaska JF: Neural activity in primary motor and dorsal premotor cortex in reaching tasks with the contralateral versus ipsilateral arm. J Neurophysiol. 2003; 89(2): 922-42.

PubMed Abstract | Publisher Full Text

61. F Cisek $P$, Kalaska JF: Neural correlates of reaching decisions in dorsal premotor cortex: specification of multiple direction choices and final selection of action. Neuron. 2005; 45(5): 801-14.

PubMed Abstract | Publisher Full Text | F1000 Recommendation

62. Churchland MM, Santhanam G, Shenoy KV: Preparatory activity in premotor and motor cortex reflects the speed of the upcoming reach. $J$ Neurophysiol. 2006; 96(6): 3130-46.

PubMed Abstract | Publisher Full Text

63. Afshar A, Santhanam G, Yu BM, et al.: Single-trial neural correlates of arm movement preparation. Neuron. 2011; 71(3): 555-64.

PubMed Abstract | Publisher Full Text | Free Full Text

64. Michaels JA, Dann B, Intveld RW, et al:: Predicting Reaction Time from the Neural State Space of the Premotor and Parietal Grasping Network. J Neurosci. 2015; 35(32): 11415-32.

PubMed Abstract | Publisher Full Text

65. F Kaufman MT, Seely JS, Sussillo D, et al.: The Largest Response Componen in the Motor Cortex Reflects Movement Timing but Not Movement Type. eNeuro. 2016; 3(4): pii: ENEURO.0085-16.2016

PubMed Abstract | Publisher Full Text | Free Full Text | F1000 Recommendation

66. Schöner G, Kelso JA: Dynamic pattern generation in behavioral and neural systems. Science. 1988; 239(4847): 1513-20.

PubMed Abstract | Publisher Full Text

67. Grillner S: Biological pattern generation: the cellular and computational logic of networks in motion. Neuron. 2006; 52(5): 751-66.

PubMed Abstract | Publisher Full Text

68. Feldman AG, Levin MF: The equilibrium-point hypothesis--past, present and future. Adv Exp Med Biol. 2009; 629: 699-726.

PubMed Abstract | Publisher Full Text

69. Hogan N, Sternad D: Dynamic primitives of motor behavior. Biol Cybern. 2012; 106(11-12): 727-39.

PubMed Abstract | Publisher Full Text | Free Full Text

70. Ijspeert AJ, Nakanishi J, Hoffmann $\mathrm{H}$, et al.: Dynamical movement primitives: learning attractor models for motor behaviors. Neural Comput. 2013; 25(2): 328-73.

PubMed Abstract | Publisher Full Text

71. Sussillo D, Churchland MM, Kaufman MT, et al:: A neural network that finds a naturalistic solution for the production of muscle activity. Nat Neurosci. 2015 18(7): 1025-33.

PubMed Abstract | Publisher Full Text | Free Full Text

72. Michaels JA, Dann B, Scherberger H: Neural Population Dynamics during Reaching Are Better Explained by a Dynamical System than Representationa Tuning. PLoS Comput Biol. 2016; 12(11): e1005175.

PubMed Abstract | Publisher Full Text | Free Full Text

73. F Lara AH, Elsayed GF, Zimnik AJ, et al:: Conservation of preparatory neural events in monkey motor cortex regardless of how movement is initiated. eLife. 2018; 7: pii: e31826.

PubMed Abstract | Publisher Full Text | Free Full Text | F1000 Recommendation

74. Kaufman MT, Churchland MM, Shenoy KV: The roles of monkey M1 neuron classes in movement preparation and execution. J Neurophysiol. 2013; 110(4): 817-25.

PubMed Abstract | Publisher Full Text | Free Full Text

75. Kaufman MT, Churchland MM, Ryu SI, et al.: Cortical activity in the null space: permitting preparation without movement. Nat Neurosci. 2014; 17(3): 440-8. PubMed Abstract | Publisher Full Text | Free Full Text

76. F Elsayed GF, Lara AH, Kaufman MT, et al.: Reorganization between preparatory and movement population responses in motor cortex. $\mathrm{Na}$ Commun. 2016; 7: 13239

PubMed Abstract | Publisher Full Text | Free Full Text | F1000 Recommendation

77. F Rouse AG, Schieber MH: Condition-Dependent Neural Dimensions Progressively Shift during Reach to Grasp. Cell Rep. 2018; 25(11): 3158-3168.e3. PubMed Abstract | Publisher Full Text | Free Full Text | F1000 Recommendation

78. F Russo AA, Bittner SR, Perkins SM, et al:: Motor Cortex Embeds Muscleike Commands in an Untangled Population Response. Neuron. 2018; 97(4) 953-966.e8.

PubMed Abstract | Publisher Full Text | Free Full Text | F1000 Recommendation

79. Pilacinski A, Lindner A: Distinct contributions of human posterior parietal and dorsal premotor cortex to reach trajectory planning. Sci Rep. 2019; 9(1): 1962. PubMed Abstract | Publisher Full Text | Free Full Text

80. Scott SH, Kalaska JF: Reaching movements with similar hand paths but different arm orientations. I. Activity of individual cells in motor cortex. J Neurophysiol. 1997; 77(2): 826-52.

PubMed Abstract | Publisher Full Text

81. Seely JS, Kaufman MT, Ryu SI, et al:: Tensor Analysis Reveals Distinct Population Structure that Parallels the Different Computational Roles of Areas M1 and V1. PLoS Comput Biol. 2016; 12(11): e1005164. PubMed Abstract | Publisher Full Text | Free Full Text

82. F Lara AH, Cunningham JP, Churchland MM: Different population dynamics in the supplementary motor area and motor cortex during reaching. Nat Commun 2018; 9(1): 2754.

PubMed Abstract | Publisher Full Text | Free Full Text | F1000 Recommendation

83. Kalaska JF, Cohen DA, Hyde ML, et al.: A comparison of movement directionrelated versus load direction-related activity in primate motor cortex, using a two-dimensional reaching task. J Neurosci. 1989; 9(6): 2080-102.

PubMed Abstract | Publisher Full Text

84. Kalaska JF, Cohen DA, Prud'homme M, et al.: Parietal area $\mathbf{5}$ neuronal activity encodes movement kinematics, not movement dynamics. Exp Brain Res. 1990; 80(2): 351-64.

PubMed Abstract | Publisher Full Text

85. Sergio LE, Hamel-Pâquet C, Kalaska JF: Motor cortex neural correlates of output kinematics and kinetics during isometric-force and arm-reaching tasks. $J$ Neurophysiol. 2005; 94(4): 2353-78.

PubMed Abstract | Publisher Full Text

86. Hamel-Pâquet C, Sergio LE, Kalaska JF: Parietal area $\mathbf{5}$ activity does not reflect the differential time-course of motor output kinetics during arm-reaching and isometric-force tasks. J Neurophysiol. 2006; 95(6): 3353-70. PubMed Abstract | Publisher Full Text

87. $\mathrm{F}$ Michaels JA, Scherberger $\mathrm{H}$ : Population coding of grasp and lateralityrelated information in the macaque fronto-parietal network. Sci Rep. 2018; 8(1) 1710

PubMed Abstract | Publisher Full Text | Free Full Text | F1000 Recommendation

88. F Michaels JA, Dann B, Intveld RW, et al.: Neural Dynamics of Variable GraspMovement Preparation in the Macaque Frontoparietal Network. J Neurosci. 2018; 38(25): 5759-73.

PubMed Abstract | Publisher Full Text | F1000 Recommendation

89. Klaes $\mathrm{C}$, Westendorff $\mathrm{S}$, Chakrabarti $\mathrm{S}$, et al:: Choosing goals, not rules: deciding among rule-based action plans. Neuron. 2011; 70(3): 536-48.

PubMed Abstract | Publisher Full Text

90. F Wallis JD, Miller EK: From rule to response: neuronal processes in the premotor and prefrontal cortex. J Neurophysiol. 2003; 90(3): 1790-806. PubMed Abstract | Publisher Full Text | F1000 Recommendation

91. Muhammad R, Wallis JD, Miller EK: A comparison of abstract rules in the prefrontal cortex, premotor cortex, inferior temporal cortex, and striatum. J Cogn Neurosci. 2006; 18(6): 974-89.

PubMed Abstract | Publisher Full Text

92. F Genovesio A, Brasted PJ, Mitz AR, et al.: Prefrontal cortex activity related to abstract response strategies. Neuron. 2005; 47(2): 307-20. PubMed Abstract | Publisher Full Text | Free Full Text | F1000 Recommendation

93. Nougaret $\mathrm{S}$, Genovesio A: Learning the meaning of new stimuli increases the cross-correlated activity of prefrontal neurons. Sci Rep. 2018; 8(1): 11680. PubMed Abstract | Publisher Full Text | Free Full Text

94. Stokes MG, Kusunoki M, Sigala N, et al:: Dynamic coding for cognitive control in prefrontal cortex. Neuron. 2013; 78(2): 364-75. PubMed Abstract | Publisher Full Text | Free Full Text

95. F Mante V, Sussillo D, Shenoy KV, et al:: Context-dependent computation by recurrent dynamics in prefrontal cortex. Nature. 2013; 503(7474): 78-84 PubMed Abstract | Publisher Full Text | Free Full Text | F1000 Recommendation

96. Elsayed GF, Cunningham JP: Structure in neural population recordings: an expected byproduct of simpler phenomena? Nat Neurosci. 2017; 20(9): 1310-8. PubMed Abstract | Publisher Full Text | Free Full Text

97. F Sadtler PT, Quick KM, Golub MD, et al:: Neural constraints on learning Nature. 2014; 512(7515): 423-6. PubMed Abstract | Publisher Full Text | Free Full Text | F1000 Recommendation

98. F Jazayeri M, Afraz A: Navigating the Neural Space in Search of the Neural Code. Neuron. 2017; 93(5): 1003-14. PubMed Abstract | Publisher Full Text | F1000 Recommendation

99. F Gallego JA, Perich MG, Miller LE, et al:: Neural Manifolds for the Control of 
Movement. Neuron. 2017; 94(5): 978-84.

PubMed Abstract | Publisher Full Text | Free Full Text | F1000 Recommendation

100. Carmena JM, Lebedev MA, Crist RE, et al: Learning to control a brain-machine interface for reaching and grasping by primates. PLOS Biol. 2003; 1(2): E42. PubMed Abstract | Publisher Full Text | Free Full Text

101. F Ganguly K, Carmena JM: Emergence of a stable cortical map for neuroprosthetic control. PLOS Biol. 2009; 7(7): e1000153. PubMed Abstract | Publisher Full Text | Free Full Text | F1000 Recommendation

102. F Ganguly K, Dimitrov DF, Wallis JD, et al:: Reversible large-scale modification of cortical networks during neuroprosthetic control. Nat Neurosci. 2011; 14(5): $662-7$.

PubMed Abstract | Publisher Full Text | Free Full Text | F1000 Recommendation

103. F Jarosiewicz B, Chase SM, Fraser GW, et al.: Functional network reorganization during learning in a brain-computer interface paradigm. Proc Natl Acad Sci U S A. 2008; 105(49): 19486-91.

PubMed Abstract | Publisher Full Text | Free Full Text | F1000 Recommendation

104. Chase SM, Kass RE, Schwartz AB: Behavioral and neural correlates of visuomotor adaptation observed through a brain-computer interface in primary motor cortex. J Neurophysiol. 2012; 108(2): 624-44. PubMed Abstract | Publisher Full Text | Free Full Text

105. F Golub MD, Sadtler PT, Oby ER, et al.: Learning by neural reassociation. Nat Neurosci. 2018; 21(4): 607-16.

PubMed Abstract | Publisher Full Text | Free Full Text | F1000 Recommendation

106. F Hennig JA, Golub MD, Lund PJ, et al:: Constraints on neural redundancy eLife. 2018; 7: pii: e36774.

PubMed Abstract | Publisher Full Text | Free Full Text | F1000 Recommendation

107. F Hwang EJ, Bailey PM, Andersen RA: Volitional control of neural activity relies on the natural motor repertoire. Curr Biol. 2013; 23(5): 353-61. PubMed Abstract | Publisher Full Text | Free Full Text | F1000 Recommendation

108. F Athalye VR, Ganguly K, Costa RM, et al.: Emergence of Coordinated Neural Dynamics Underlies Neuroprosthetic Learning and Skillful Control. Neuron. 2017; 93(4): 955-970.e5

PubMed Abstract | Publisher Full Text | F1000 Recommendation

109. Jun JJ, Steinmetz NA, Siegle JH, et al:: Fully integrated silicon probes for highdensity recording of neural activity. Nature. 2017; 551(7679): 232-6. PubMed Abstract | Publisher Full Text | Free Full Text

110. Steinmetz NA, Koch C, Harris KD, et al.: Challenges and opportunities for largescale electrophysiology with Neuropixels probes. Curr Opin Neurobiol. 2018; 50: $92-100$.

PubMed Abstract | Publisher Full Text | Free Full Text

111. F Ohki K, Chung S, Ch'ng YH, et al:: Functional imaging with cellular resolution reveals precise micro-architecture in visual cortex. Nature. 2005; 433(7026): 597-603.

PubMed Abstract | Publisher Full Text | F1000 Recommendation

112. Ohkura M, Sasaki T, Sadakari J, et al.: Genetically encoded green fluorescent $\mathrm{Ca}^{2+}$ indicators with improved detectability for neuronal $\mathrm{Ca}^{2+}$ signals. PLOS One. 2012; 7(12): e51286.

PubMed Abstract | Publisher Full Text | Free Full Text

113. Carrillo-Reid L, Yang W, Kang Miller JE, et al.: Imaging and Optically Manipulating Neuronal Ensembles. Annu Rev Biophys. 2017; 46: 271-93. PubMed Abstract | Publisher Full Text

114. Yizhar O, Fenno LE, Davidson TJ, et al:: Optogenetics in neural systems. Neuron. 2011; 71(1): 9-34.

PubMed Abstract | Publisher Full Text

115. F Komiyama T, Sato TR, O'Connor DH, et al.: Learning-related fine-scale specificity imaged in motor cortex circuits of behaving mice. Nature. 2010; 464(7292): 1182-6.

PubMed Abstract | Publisher Full Text | F1000 Recommendation

116. F Harvey $C D$, Coen $P$, Tank DW: Choice-specific sequences in parietal cortex during a virtual-navigation decision task. Nature. 2012; 484(7392): 62-8. PubMed Abstract | Publisher Full Text | Free Full Text | F1000 Recommendation

117. F Huber D, Gutnisky DA, Peron S, et al:: Multiple dynamic representations in the motor cortex during sensorimotor learning. Nature. 2012; 484(7395): 473-8. PubMed Abstract | Publisher Full Text | Free Full Text | F1000 Recommendation

118. F Peters AJ, Chen SX, Komiyama T: Emergence of reproducible spatiotemporal activity during motor learning. Nature. 2014; 510(7504): 263-7. PubMed Abstract | Publisher Full Text | F1000 Recommendation

119. Masamizu Y, Tanaka YR, Tanaka YH, et al.: Two distinct layer-specific dynamics of cortical ensembles during learning of a motor task. Nat Neurosci. 2014; 17(7): 987-94.

PubMed Abstract | Publisher Full Text

120. F Li N, Chen TW, Guo ZV, et al:: A motor cortex circuit for motor planning and movement. Nature. 2015; 519(7541): 51-6. PubMed Abstract | Publisher Full Text | F1000 Recommendation

121. Chen SX, Kim AN, Peters AJ, et al.: Subtype-specific plasticity of inhibitory circuits in motor cortex during motor learning. Nat Neurosci. 2015; 18(8): 1109-15.

PubMed Abstract | Publisher Full Text | Free Full Text
122. Li N, Daie K, Svoboda K, et al.: Robust neuronal dynamics in premotor cortex during motor planning. Nature. 2016; 532(7600): 459-64.

PubMed Abstract | Publisher Full Text | Free Full Text

123. Morcos AS, Harvey $C D$ : History-dependent variability in population dynamics during evidence accumulation in cortex. Nat Neurosci. 2016; 19(12): 1672-81. PubMed Abstract | Publisher Full Text | Free Full Text

124. Chen TW, Li N, Daie K, et al:: A Map of Anticipatory Activity in Mouse Motor Cortex. Neuron. 2017: 94(4): 866-879.e4. PubMed Abstract | Publisher Full Text

125. Makino $\mathrm{H}$, Ren $\mathrm{C}$, Liu H, et al.: Transformation of Cortex-wide Emergent Properties during Motor Learning. Neuron. 2017; 94(4): 880-890.e8. PubMed Abstract | Publisher Full Text | Free Full Text

126. F Pho GN, Goard MJ, Woodson J, et al.: Task-dependent representations of stimulus and choice in mouse parietal cortex. Nat Commun. 2018; 9(1): 2596. PubMed Abstract | Publisher Full Text | Free Full Text | F1000 Recommendation

127. F Han X, Qian X, Bernstein JG, et al:: Millisecond-timescale optical control of neural dynamics in the nonhuman primate brain. Neuron. 2009; 62(2): 191-8. PubMed Abstract | Publisher Full Text | Free Full Text | F1000 Recommendation

128. Diester I, Kaufman MT, Mogri M, et al.: An optogenetic toolbox designed for primates. Nat Neurosci. 2011; 14(3): 387-97. PubMed Abstract | Publisher Full Text | Free Full Text

129. O'Shea DJ, Trautmann E, Chandrasekaran C, et al:: The need for calcium imaging in nonhuman primates: New motor neuroscience and brain-machine interfaces. Exp Neurol. 2017; 287(Pt 4): 437-51. PubMed Abstract | Publisher Full Text | Free Full Text

130. F Galvan A, Stauffer WR, Acker L, et al: Nonhuman Primate Optogenetics: Recent Advances and Future Directions. J Neurosci. 2017; 37(45): 10894-903. PubMed Abstract | Publisher Full Text | Free Full Text | F1000 Recommendation

131. F O'Shea DJ, Kalanithi P, Ferenczi EA, et al.: Development of an optogenetic toolkit for neural circuit dissection in squirrel monkeys. Sci Rep. 2018; 8(1): 6775.

PubMed Abstract | Publisher Full Text | Free Full Text | F1000 Recommendation

132. Heider $B$, Nathanson JL, Isacoff $E Y$, et al.: Two-photon imaging of calcium in virally transfected striate cortical neurons of behaving monkey. PLOS One. 2010; 5(11): e13829.

PubMed Abstract | Publisher Full Text | Free Full Text

133. Yazdan-Shahmorad A, Diaz-Botia C, Hanson TL, et al:: A Large-Scale Interface for Optogenetic Stimulation and Recording in Nonhuman Primates. Neuron. 2016; 89(5): 927-39. PubMed Abstract | Publisher Full Text

134. Seidemann $E$, Chen $\mathrm{Y}$, Bai $\mathrm{Y}$, et al.: Calcium imaging with genetically encoded indicators in behaving primates. eLife. 2016; 5: pii: e16178. PubMed Abstract | Publisher Full Text | Free Full Text

135. $\mathrm{F}$ Li M, Liu F, Jiang $\mathrm{H}$, et al.: Long-Term Two-Photon Imaging in Awake Macaque Monkey. Neuron. 2017; 93(5): 1049-1057.e3. PubMed Abstract | Publisher Full Text | F1000 Recommendation

136. F Tang S, Lee TS, Li M, et al.: Complex Pattern Selectivity in Macaque Primary Visual Cortex Revealed by Large-Scale Two-Photon Imaging. Curr Biol. 2018; 28(1): 38-48

PubMed Abstract | Publisher Full Text | F1000 Recommendation

137. $\mathrm{F}$ Tang $\mathrm{S}$, Zhang $\mathrm{Y}$, Li Z, et al.: Large-scale two-photon imaging revealed super-sparse population codes in the V1 superficial layer of awake monkeys. eLife. 2018; 7: pii: e33370.

PubMed Abstract | Publisher Full Text | Free Full Text | F1000 Recommendation

138. F Yazdan-Shahmorad A, Silversmith DB, Kharazia V, et al:: Targeted cortical reorganization using optogenetics in non-human primates. eLife. 2018; 7 pii: e31034.

PubMed Abstract | Publisher Full Text | Free Full Text | F1000 Recommendation

139. F Ju N, Jiang R, Macknik SL, et al.: Long-term all-optical interrogation of cortical neurons in awake-behaving nonhuman primates. PLOS Biol. 2018; 16(8): e2005839.

PubMed Abstract | Publisher Full Text | Free Full Text | F1000 Recommendation

140. Sadakane O, Masamizu Y, Watakabe A, et al.: Long-Term Two-Photon Calcium Imaging of Neuronal Populations with Subcellular Resolution in Adult Nonhuman Primates. Cell Rep. 2015; 13(9): 1989-99. PubMed Abstract | Publisher Full Text

141. Santisakultarm TP, Kersbergen CJ, Bandy DK, et al:: Two-photon imaging of cerebral hemodynamics and neural activity in awake and anesthetized marmosets. J Neurosci Methods. 2016; 271: 55-64. PubMed Abstract | Publisher Full Text | Free Full Text

142. Yamada $\mathrm{Y}$, Matsumoto $\mathrm{Y}$, Okahara $\mathrm{N}$, et al:: Chronic multiscale imaging of neuronal activity in the awake common marmoset. Sci Rep. 2016; 6: 35722 PubMed Abstract | Publisher Full Text | Free Full Text

143. F Ebina T, Masamizu Y, Tanaka YR, et al:: Two-photon imaging of neuronal activity in motor cortex of marmosets during upper-limb movement tasks. Nat Commun. 2018; 9(1): 1879.

PubMed Abstract | Publisher Full Text | Free Full Text | F1000 Recommendation

144. Ouzounov DG, Wang T, Wang M, et al.: In vivo three-photon imaging of activity of GCaMP6-labeled neurons deep in intact mouse brain. Nat Methods. 2017; 
14(4): 388-90.

PubMed Abstract | Publisher Full Text | Free Full Text

145. Kondo M, Kobayashi K, Ohkura M, et al:: Two-photon calcium imaging of the medial prefrontal cortex and hippocampus without cortical invasion. eLife. 2017; 6: pii: e26839.

PubMed Abstract | Publisher Full Text | Free Full Text

146. Birkner A, Tischbirek CH, Konnerth A: Improved deep two-photon calcium imaging in vivo. Cell Calcium. 2017; 64: 29-35.

PubMed Abstract | Publisher Full Text

147. Ohayon S, Caravaca-Aguirre A, Piestun R, et al:: Minimally invasive multimode optical fiber microendoscope for deep brain fluorescence imaging. Biomed Opt Express. 2018; 9(4): 1492-509. PubMed Abstract | Publisher Full Text | Free Full Text

148. Sofroniew NJ, Flickinger D, King J, et al:: A large field of view two-photon mesoscope with subcellular resolution for in vivo imaging. eLife. 2016; 5 pii: e14472.

PubMled Abstract | Publisher Full Text | Free Full Text

149. F Yoshida $\mathrm{E}$, Terada SI, Tanaka $\mathrm{YH}$, et al.: In vivo wide-field calcium imaging of mouse thalamocortical synapses with an $8 \mathrm{~K}$ ultra-high-definition camera. Sci Rep. 2018; 8(1): 8324

PubMed Abstract | Publisher Full Text | Free Full Text | F1000 Recommendation

150. F Terada SI, Kobayashi K, Ohkura M, et al.: Super-wide-field two-photon imaging with a micro-optical device moving in post-objective space. $\mathrm{Nat}$ Commun. 2018; 9(1): 3550.

PubMed Abstract | Publisher Full Text | Free Full Text | F1000 Recommendation

151. Sun X, Kao JC, Marshel JH, et al.: Feasibility analysis of genetically-encoded calcium indicators as a neural signal source for all-optical brain-machine interfaces. 8th International IEE/EMBS Conference on Neural Engineering (NER) 2017; 174-180.

Publisher Full Text 


\section{Open Peer Review}

\section{Current Peer Review Status:}

\section{Editorial Note on the Review Process}

Faculty Reviews are review articles written by the prestigious Members of Faculty Opinions. The articles are commissioned and peer reviewed before publication to ensure that the final, published version is comprehensive and accessible. The reviewers who approved the final version are listed with their names and affiliations.

\section{The reviewers who approved this article are:}

\section{Version 1}

\section{Hansjörg Scherberger}

Faculty of Biology and Psychology, University of Göttingen, Göttingen, Germany Competing Interests: No competing interests were disclosed.

\section{Byron Yu}

Departments of Biomedical Engineering and Electrical \& Computer Engineering, Carnegie Mellon University, Pittsburgh, PA, USA

Competing Interests: No competing interests were disclosed.

\section{John P Cunningham} Department of Statistics, Grossman Center for the Statistics of Mind, Zuckerman Mind Brain Behavior Institute, Center for Theoretical Neuroscience, Columbia University, New York, USA Competing Interests: No competing interests were disclosed.

\section{Steve Chase}

Department of Biomedical Engineering, Carnegie Mellon University, Pittsburgh, USA

Competing Interests: No competing interests were disclosed. 
The benefits of publishing with F1000Research:

- Your article is published within days, with no editorial bias

- You can publish traditional articles, null/negative results, case reports, data notes and more

- The peer review process is transparent and collaborative

- Your article is indexed in PubMed after passing peer review

- Dedicated customer support at every stage

For pre-submission enquiries, contact research@f1000.com 